\title{
THE HISTORICITY OF MUSIC IN HEGEL IN FACE OF SCHOENBERG'S TWELVE-TONE MUSIC'
}

\author{
A historicidade da música em Hegel diante da música \\ dodecafônica de Schoenberg \\ La historicidad de la música en Hegel frente la música \\ dodecafónica de Schoenberg
}

Adriano Bueno Kurle ${ }^{2}$

Federal University of Mato Grosso

\begin{abstract}
In this paper, I consider how it would be possible to think about the historicity of music through Hegel's thought. I will compare Hegel's idea with a historical event that is considered relevant in the history of music: Schoenberg's twelve-tone music, taken here also as a model of immanent negation and Aufhebung of tonal system in music. Furthermore, I will take Schoenberg's twelve-tone music as an instance and wonder about the role of music and its history in the sociocultural formation (or, in Hegelian words, in the absolute Geist). I divide the exposition into four parts, namely: (1) the position of art before the
\end{abstract}

\footnotetext{
This study was financed in part by the Coordenação de Aperfeiçoamento de Pessoal de Nível Superior - Brasil (CAPES) - Finance Code 001.

2 Doctor in Philosophy by Pontifical Catholic University of Rio Grande do Sul. Adjunct Professor at Departament of Philosophy, Institute of Human and Social Sciences, Federal University of Mato Grosso, Cuiabá, Mato Grosso, Brazil. http://orcid.org/0000-0002-9745-1830. E-mail:adrianobk@gmail.com
} 
absolute Geist; (2) a general exposition of art in the Lectures on the Philosophy of Art, placing music as a singular form of art; (3) an analysis of the characteristics of music in Hegel and (4) the comparison with Schoenberg's twelve-tone music. I conclude that music, as an artistic form, brings the form of an internal feeling of a social subjectivity - a way to feel and understand sounds that transforms itself through history; in turn, both music and the form of an internal feeling of social subjectivity, have a historicity that can be understood as developed dialectically. Along these lines, the beginning of the Twentieth Century in music reveals, through Schoenberg and other composers, new intuitive configurations of this social subjectivity.

Keywords: Hegel, Historicity, Music, Schoenberg, Twelve-tone music.

\section{Resumo}

Neste artigo, considero como seria possível pensar a historicidade da música por meio do pensamento de Hegel. Confrontarei as ideias de Hegel com um evento histórico que é considerado relevante na história da música: a música dodecafônica de Schoenberg, considerada aqui modelo de negação imanente e de Aufhebung do sistema tonal em música. Neste artigo, tomo a música dodecafônica de Schoenberg como um exemplar e questiono sobre o papel da música e de sua historicidade na formação sociocultural (ou, em termos hegelianos, no Geist absoluto). Divido a exposição em quatro partes, a saber (1) a posição da arte diante do Geist absoluto; (2) a exposição geral da arte nos Cursos de Filosofia da Arte, situando a música enquanto forma de arte singular; (3) uma análise das características da música em Hegel e (4) a confrontação com a música dodecafônica de Schoenberg. Eu concluo que a música, enquanto forma artística, traz a forma do sentido interior de uma subjetividade social, um modo de sentir e de compreender sons que se transforma através da história - e que têm, tanto a música quanto a forma interna da subjetividade social, uma historicidade que pode ser compreendida dialeticamente. Neste sentido, o início do século XX na música revela, com Schoenberg e outros compositores, novas configurações intuitivas desta subjetividade social.

Palavras-chave: Historicidade, Hegel, Música, Schoenberg, Dodecafonismo.

\section{Resumen}

En este artículo, la reflexión visa discutir como sería posible pensar la historicidad de la musica a través del pensamiento de Hegel. Se oponen a las ideas de Hegel con un acontecimiento histórico que se considera relevante en la historia de la música: la música dodecafónica de Schoenberg, se considera aquí como un modelo de negación 
inmanente y de Aufhebung en el sistema tonal en la música. En este artículo, tomo la música dodecafónica de Schoenberg como un ejemplar y cuestiono sobre el papel de la música y su historicidad en la formación socio-cultural (o, en términos hegelianos, en el Geist absoluto). Divido la exposición en cuatro partes, a saber: (1) la posición del arte en el Geist absoluto; (2) la exposición general del arte de los Cursos de la Filosofía del Arte, colocando la música como forma de arte singular; (3) un análisis de las características de la música en Hegel y (4) la confrontación con el dodecafonismo de Schoenberg. Concluyo que la música, mientras sea forma artística, trae la forma de sentido interior de una subjetividad social, una manera de sentir y entender los sonido, que si se transforman a lo largo de la historia - y que tienen, tanto la música cuanto la forma interna de la subjetividad social, una historicidad que puede ser entendida dialécticamente. En este sentido, los principios del siglo XX en la música muestran, con Schoenberg y otros compositores, nuevas configuraciones intuitivas de esta subjetividad social.

Palabras clave: Historicidad, Hegel, Dodecafonismo, Musica, Schoenberg.

\section{Introduction}

Hegel's philosophy combines logic and history in a way that collaborates with the understanding of social and human events, especially in connection to the rise of modernity. Hegel maintains a place for ideality in material phenomena and through the passage of time, ensuring a source of meaning to historical events, preventing thought and history to become two different spheres or to be incorporated into one another. There is no meaning to an object or event outside the relationship between materiality (represented by the category of singular) and ideality (represented by the category of universal). Along these lines, there is no meaning to historical events outside logic and ideality, which for Hegel are immanent to the historical process itself. On the other hand, the historical process is a manifestation of ideality since it is impossible to say that ideality predetermines history - history is the place of thinking, without which no thought would be possible.

For that reason, Hegel's philosophy becomes even more fruitful when applied to particular objects or sciences. As I will present in this paper, that 
is the case with art and music. Through philosophy, Hegel searches for the concept of art, which must involve its role as universal (through the definition of the Ideal, as sensible manifestation of the Idea), as particular (as historical manifestation of the different meanings and levels of social self-consciousness revealed by art) and as singular (through the material and the senses that are involved in the artistic manifestation). ${ }^{3}$ Art constitutes a whole, ${ }^{4}$ which, in turn, fulfills a role in the general formation of Geist and, specifically, in the absolute Geist. ${ }^{5}$

Art is one of the forms of cultural self-comprehension where social subjectivity and social objectivity meet. By itself, music constitutes one of the singular forms of art. As such, it is possible to contrast Hegel's analysis of music and historical forms of art with the history of music. ${ }^{6}$ Considering that in the specific part where Hegel analyzes music as singular art he does not explicitly explore the issue of the historicity of music, in this paper I would like to examine how it would be possible to think about the historicity of music through Hegel's thought. Thus, there is an affirmation that music is a romantic particular form of art, ${ }^{7}$ and that music

\footnotetext{
3 See G. W. F. Hegel, Werke 13: Vorlesungen über die Ästhetik I (Frankfurt am Main: Suhrkamp, 1989); G. W. F. Hegel, Werke 14: Vorlesungen über die Ästhetik II (Frankfurt am Main: Suhrkamp, 1990); G. W. F. Hegel, Werke 15: Vorlesungen über die Ästhetik III (Frankfurt am Main: Suhrkamp, 1990); G. W. F. Hegel, Die Idee Und Das Ideal, ed. Georg Lasson (Leipzig: Meiner, 1931); G. W. F. Hegel, Vorlesungen über die Philosophie der Kunst, ed. Annemarie Gethmann-Siefert (Hamburg: Meiner, 2003).

4 See Hegel, Asthetik II, 245 - 246.

5 See G. W. F. Hegel, Werke 10: Enzyklopädie der philosophischen Wissenschaften III (Frankfurt am Main: Suhrkamp, 1986), §§553-563. The German word "Geist" is usually translated as "spirit" or, in some cases, "mind." For technical specificity and to avoid other "mystical" or esoteric interpretations (as if it could mean "individual soul" or a "ghost", as immaterial substance), I will from now on write the word in German. For a Hegelian critique of esoteric views, see G. W. F. Hegel, Werke 3: Phänomenologie des Geistes (Frankfurt am Main: Suhrkamp, 1989), 19-21.

${ }_{6}$ I take here Western Classical Music from Baroque to beginning of $20^{\text {th }}$ Century, keeping in mind the development of tonal system in this time period until its saturation and Aufhebung in Schoenberg. The main bibliographical references in History of Music are Roland Candé, História Universal da Música. 2 Vols. Translated by Eduardo Brandão (São Paulo: Martins Fontes, 2001); Otto Maria Carpeaux, O Livro de Ouro da História da Música: Da Idade Média ao século XX. Fifth edition (Rio De Janeiro: Ediouro, 2001); E. A. Denham, The Future of Tonality. In: British Journal of Aesthetics, vol. 49, n. 4, 427-450; D. Grout; C. Palisca, História da Música Ocidental. 5 th ed. Translated by Ana Luísa Maria (Lisboa: Gradiva, 2007).
}

7 See Hegel, Vorlesungen über die Philosophie der Kunst, 45; Hegel, Ästhetik I, 140-141. 
fulfills a specific role to the realization of this historical form. The process that is immanent to the romantic form, the passage from a religious role to a secular moment, and the overcoming of art as a privileged form of comprehension of the absolute Geist by religion and by philosophy, will be approached through what came to be called "the declaration of the end of art" by Hegel. ${ }^{8}$ In order to contrast the history of music with this supposedly Hegelian idea of the end of art,, 9 I will confront Hegel's idea with a historical event that is considered relevant and new in the history of music and, as such, also important to cultural history: Schoenberg's twelve-tone music, seen here also as a model of immanent negation and Aufhebung of tonal system in music. There is, then, an affirmation that music is a romantic particular form of art and that it fulfills a specific function to the realization of this historical and particular form of art.

In this paper I attempt to examine the issue by taking Schoenberg's twelve-tone music as an instance and deliberating the role of music and its history in the sociocultural formation (or, based on Pippin's interpretation, in the absolute Geist ${ }^{10}$ ), despite the modern times' prosaism" and the overcoming of art as a privileged way of realization of the Idea in Hegel's thought.

I divide the exposition into four parts, namely: (1) the position of art before the absolute Geist and the analogy between intuition in the subjec-

\footnotetext{
8 See Ibid., 25-26; M. A. Werle, A Questão do Fim da Arte em Hegel (São Paulo: Hedra, 2011); Robert Pippin, After the Beautiful: Hegel and the Philosophy of Pictorial Modernism (Chicago: University of Chicago Press, 2014), 27-62.

9 One should not believe that the claim that art is something of the past (ein Vergangenes) is to say that art has an end. This point is crucial in the discussion about end of art in Hegel, and that is why I use the word "supposedly". Some defend the idea of a continuity (so, a non-end of art) in Hegel's conception of art history, while others believe that the "pastness" of art also means the end of art or use it to justify the idea that art history has an end in Hegel's philosophy. For more references on this discussion, see Benjamin Rutter, Hegel on Modern Arts (Cambridge: Cambridge University Press, 2010), 06.

10 See Pippin, After the Beautiful, 09, 17-19, 22, 25-26.

"See Hegel, Ästhetik I., 253-255; Marcia Gonçalves, "Tempo Poético e Tempo Prosaico," Revista Eletrônica Estudos Hegelianos 14, no. 23 (2017), http://ojs.hegelbrasil.org/index.php/ reh/article/view/232/200; J. D. Hernández, "A arte como formelle Bildung: a estética de Hegel e o mundo moderno," in Arte e Filosofia no Idealismo Alemão, ed. M. A. Werle and P. F. Galé (São Paulo: Editora Barcarolla, 2009), 77-104.
} 
tive Geist, and art in the absolute Geist; (2) a general exposition of art in the Lectures on the Philosophy of Art, placing music as a singular form of art; (3) an analysis of the characteristics of music in Hegel, the evaluation of its historicity and (4) the confrontation with Schoenberg's twelve-tone music and his view on harmony. I conclude that music, as artistic form, brings the form of an internal feeling of a social subjectivity - a way to feel and understand sounds that transforms itself throughout history - which therefore has dialectical immanent historicity. In these lines the beginning of the Twentieth Century in music reveals, through Schoenberg and other composers, new intuitive configurations of this social subjectivity. ${ }^{12}$

\section{Geist and Art}

In order to understand the place of art in Hegel's thought, one must first understand its basic concepts. Art must be conceptualized in its proper place, which is the absolute Geist. In turn, the general structure of Hegel's thought must be understood in order to develop a perception of the absolute Geist. The concept of Geist is constructed through the relationship with Idea (logic) and Nature.

Geist is characterized as being the activity through which the material event generates forms of self-recognition. ${ }^{13}$ Geist is a reflexive activity

\footnotetext{
12 This article intends to bring a contextualization of music in Hegel's general system, conceived mainly through the relation between Encyclopedia's Philosophy of Geist and the Lectures on Philosophy of Art. The main aim of this contextualization is to show the place of music and its relationship to historicity (thought dialectically). I chose a form of presentation in which the relationship between music and the historical development of romantic particular form of art is not fully or even properly developed, since I intend to do that in a separate article.

13 Some (for instance G. S. Hall "Hegel's Science of Absolute Spirit" in The Journal of Speculative Philosophy, 7 no. 3 (1873), 46-47) would say that Geist is God. I do not agree with this interpretation, for two main reasons: first, that would lead us to a pantheistic interpretation of God, since Geist realizes itself in material reality and in history. If Geist needs realization, this implies that God is not realized. I do not think Hegel would take this interpretation on God, given that he has a Christian view. Second, a non-theological interpretation of Geist allows a richer and broader conception. God is a perspective of Geist, but they are are not identical, because I cannot translate every use of Geist by "God" - otherwise we would be allowed to say that human subjects are gods, for instance.
} 


\section{[Tätigkeit], and its realization is the self-identification of this activity. ${ }^{14} \mathrm{Hegel}$} divides this stage into three parts: the subjective side, the objective side and the absolute. The subjective side is the moment of individual identity constitution and of consciousness, a process that is divided by Hegel into three parts: anthropology, phenomenology, and psychology. ${ }^{15}$ On the objective side, there is the constitution of the relationship between self-consciousnesses that already know their free will and express themselves through intersubjective and social relations These expressions pass through mediations that lead to the concretization of what Hegel calls "universal,"

14 There are, generally speaking, three possible lines of interpretation of Geist, taking the relation Geist-Natur as reference point: two monisms (one reducing nature to Geist's processes, the other reducing spiritual processes to nature) and dualism. My interpretation tries to follow a monistic interpretation, through a conception of nature that includes in itself the spiritual elements that it generates. Peters presents John McCumber and Terry Pinkard as two representatives of a view in which nature and Geist are continuous (a monistic naturalist view). She argues that McCumber does not solve the radical difference between will and natural activity (which should be continuous). Pinkard, in turn, distinguishes between inner and outer in the animal, the outer being the animal's purpose. Bringing the outer to the inner is a kind of organic activity that Pinkard uses to relate to self-activity to which mentality is continuous. One difference between animal and human mental activity is that humans can distinguish between a sensation and what it is a sensation of (thus, it rises the distinction between subject and object). Also, humans are able to respond to reasons as reasons (reason-guide behavior). Peters's critique goes as follows: "In this way, Pinkard's interpretation offers resources for holding on to the idea that spirit and nature are distinct, while at the same time insisting on their continuity. They are continuous in the sense that the activity which is constitutive of human mentality has the same purpose as activities which are essential to animal mentality: both aim at maintaining a self-relation against an external world. However, this activity is running in different ways in the two cases. In the human case, it is running in a reason-guided way, involving the capacity to abstract from natural particularity (and ascend to universality). In the animal case, in contrast, it is running in an immediate, non-reflective, instinctive way." Instead of a continuous view on the relation nature-Geist, Peters argues for a view in which Geist and nature are not continuous, but they are unified (what sounds pretty Cartesian): "I suggest, by considering that he conceives of spirit and nature as unified, rather than merely as continuous. The unity in question is, however, not a reductive one which neutralizes the differences between spirit and nature. Rather, it is a unity within which they are maintained as distinct, to a certain extent even as opposed elements." Her arguments take the dual conceptions of negative and appropriative liberating of Geist in relationship to an analysis of mechanical learning to show that activity includes nature in itself, as a subject includes a predicate in a Kantian analytical judgment. See Julia Peters "On Naturalism in Hegel's Philosophy of Spirit" in British Journal for the History of Philosophy, 24:1, 111-131. This analysis is focused on Encyclopedia's Anthropology and in the body-soul relation. It might be possible to apply this view on absolute Geist, but it seems to me that we would have problems dealing with individual freedom, that would be considered as "included" in absolute Geist's activity.

15 Hegel, Enzyklopädie III, §§ 440-468. 
which until then was only something abstract, and becomes instituted and objective through social relation. It is through social relation that human beings put reason before itself, and the relationship between self-conscious agents allows that reason (in the broad sense) to both materialize itself and recognize itself in a self-reference. ${ }^{16}$ At the moment in which there is a recognition of a self-conscious unity between the individual consciousnesses, there is a passage to history and to the absolute Geist. ${ }^{17}$.

Here the moment of the absolute Geist is what matters most because it is where art finds its place. Since the Absolute can be understood as the position where there is no distinction between subject and object, the 'absolute' as a predicate of "Geist" characterizes Geist's self-relation as an activity in which the spiritual products are recognized and thematized as being Geist's own constitution. Absolute Geist is considered infinite, since it does not have a limiting otherness, while the subjective Geist and the objective Geist find themselves in separated spheres, limiting one another - so they are finite (according to Hegel's conception that every otherness is a limitation and a negation). ${ }^{18}$ The absolute Geist is therefore both the

16 “Hegel especially has in mind a way of understanding ourselves, without an 'antinomy' or contradiction, both as natural bodies in space and time and as reason-responsive thinking and acting agents, who resolve what to believe and what to do in a way for which they are responsible, in his language both as Natur and as Geist." Pippin, After the Beautiful, p. 06.

17 Ibid., $\S \S 553-577$. This affirmation must not be understood as an equalization between the conceptions of History and absolute Geist.

18 See for instance G. W. F. Hegel, "Glauben und Wissen oder Reflexionsphilosophie der Subjektivität in der Vollständigkeit ihrer Formen als Kantische, Jacobische und Fichtesche Philosophie", in Werke 2: Jenaer Schriften: 1801 - 1807 (Frankfurt am Main: Suhrkamp, 1990), 301; Yolanda Espiña says that 'Spinoza's expression 'omnia determinatio est negatio' [every determination is negation] is literally taken in Hegelian terms: the ground of every determination is the negation. If we did not think the existent as having a limit, i.e. as something determined, this thing would be the whole, and it cannot be the case, once it contradicts by its own ground what the immediate experience shows, namely the fact of multiplicity. It also contradicts the essence of thinking about the finite, namely that it is limited. Nevertheless, a finite existent does not simply exist, as a sphere closed in itself, once its own limit establishes a relationship. Saying that something has a limit means on its turn that it refers to something other than itself. The consideration of the limit means a reference to the no-being of this thing. The limit is 'the negative of itself' [Hegel, Phänomenologie, 590]. Actually, the limit is also what the existent, affirmed (positively) by its limit, is not. However, this no-being of what it is cannot be considered, says Hegel, a simply nothing, a mere no-being, but a 'nothing that is (seiendes 
moment of rational manifestation in history and the process of becoming subjective to what until then was alienated for subjectivity and for ideality. The absolute Geist gives ideal meaning to materiality and gives materiality to the ideal. This happens through three types of mediation: art, religion, and philosophy. In turn, the absolute Geist's forms of expression have an analogical relationship with the subjective Geist's forms in the level of psychology.

First, the general structure of the subjective Geist must be considered: the anthropology refers to those moments in which pulses, passions, and feelings are placed and later connected in unity, on the preconscious level - it deals with soul. In what Hegel calls phenomenology, the phenomenon of consciousness is presented, first as awareness of objects and later as self-awareness (opposed to the other, in a general manner), and at last as reason (in a strict sense), as the awareness of the unity between self and objects (it could be said "the world", included here as being-in-the-world and other self-consciousness). In the Encyclopedia, this is the moment of arrival/advent in what Hegel called psychology. ${ }^{19}$ Considering that this book was written to be used as a sketch to Hegel's classes, it is also possible to address that in the Phenomenology of Spirit the passage of the self-consciousness to the relationship between self-consciousnesses signals the appearance of Geist. ${ }^{20}$

In the level of psychology, there already is the knowledge of self as being in the world (in difference of consciousness, where the world is seen as pure otherness); this knowledge being divided in the forms of intuition, representation and thinking. ${ }^{21}$ The logical function of intuition is to bring something that is given immediately, where there is an immediate unity between the inside and the outside, between the object and the subject. It

Nichts), or what we call an other.' [G. W. F. Hegel, Werke 8: Enzyklopädie der philosophischen Wissenschaften I (Frankfurt am Main: Suhrkamp, 1986), §92] That is to say, the limit is also the other." Y. Espiña, La Razón Musical en Hegel (Navarra: Ediciones Universidad de Navarra, 1996), 38. Italics by the author.

19 See Hegel, Enzyklopädie III.

20 See Hegel, Phänomenologie, 144-145.

${ }^{21}$ See Hegel, Enzyklopädie III, §§ 445-468. 
is the case of what could be called sensations and emotions. Hegel makes a connection between sensations (which also appear in anthropology) and emotions to attention and to "intuition in narrow sense,"22 in which there is the process of distinction and new synthesis between what the subject feels and the cause of the feeling. The intuition is the sensible source, connected with that which is vanishing and related to singularity. Representation, on the other hand, brings elevation of the singular to the universal, comparing the singular types brought to intuition and connected in the universal, bringing the separation (essential characteristic of representation) between the singular and the universal. ${ }^{23}$ Thinking works on the universal level and connects the universality of these singularities through unification between universal, particular and singular, working through the activity of categorization, syllogism, inference, and consciousness of the unity between these processes. ${ }^{24}$

\section{The concept of art}

It is important to remark that Hegel makes an analogy between the functions of art, religion, and philosophy (in the level of the absolute Geist), and the functions of intuition, representation and thinking (in the level of the subjective Geist). They are levels of the absolute Geist's self-comprehension. I interpret this as degrees of the identity and unity of social mediation between subjectivities that form, in Hegel's perspective, a subjective unity broader than the individual human. ${ }^{25}$

Art is analogous to intuition in the sense that it is the sensible manifestation of Idea ${ }^{26}$ - which regulates itself through what Hegel calls

\footnotetext{
22 See lbid., $\$ 445$.

23 See Ibid., §§ 451-464.

24 See lbid., $\S \S 465-468$.

25 Robert Pippin has a similar interpretation of the absolute Geist. See Pippin, After the Beautiful.

26 See Hegel, Ästhetik I, 151.
} 
Ideal. ${ }^{27}$ The first form of perception must occur through sensibility and materiality. Artistic creation uses the sensible manifestation as a mean, but the work of art and the artistic activity do not limit themselves to it: the work of art brings an intention of meaning. It is the social self-conception in searching for a rational identity (which is the Idea). Thus, art develops itself on three levels: on the universal level its concept is determined by its function in the absolute Geist and by the concept of Ideal; on the level of particular it represents the degree of historical development of its social self-consciousness, and on the level of singular it is determined by the material and its modes of sensible expression. ${ }^{28}$

With the distinction between different ways to relate form and content, Hegel develops what he calls "particular forms of art," which are modes of historical expression of the artistic consciousness. ${ }^{29}$ The particular form of art depends on the way of conceiving and manifesting the content (the Absolute) and the way in which it expresses or conceives itself in material and natural reality (the form). Hegel distinguishes between three types of particular forms of art: symbolic art, classical art, and romantic art. The phenomenological and historical development of art-forms, through the relation of form and content, constitutes a totality of art-forms, which follow the logical path of the concept of art, oriented by the Ideal.

According to Hegel

[...] symbolic art seeks that perfect unity of inner meaning and external shape which classical art finds in the presentation of substantial individuality to sensuous contemplation, and which romantic art transcends in its superior spirituality. ${ }^{30}$

\footnotetext{
27 See lbid., 104-105; Romano Pocai, Philosophie, Kunst und Moderne: Überlegungen mit Hegel und Adorno (Berlin: Xenomoi, 2014), 135.

${ }_{28}$ See Hegel, Ästhetik I, 104; G. W. Bertram, Kunst: Eine philosophische Einführung (Stuttgart: Philipp Reclam, 2011), 80-90.

29 See Hegel, Ästhetik I; Hegel, Asthetik II.

30 Hegel, Ästhetik I, 392. Emphasis in the original. English translation: G. W. F. Hegel, Aesthetics I: Lectures on Fine Art, trans. T. M. Knox (Oxford: Clarendon Press, 1988), 302.
} 
The singular arts are defined by the material (bound to the sensible and to sensibility) with which the artistic expression is connected. Hegel divides the singular arts in five: architecture, sculpture, painting, music, and poetry. ${ }^{31}$

There is a logical progression from one singular art to the other, in accordance with the historical rule of particularization of art: first comes the visual arts, which are more connected to the physical world, to the weight of matter - architecture and sculpture. These work mainly as symbolic art (in the case of architecture) and classical (in the case of both architecture and sculpture). Painting is the visual art that touches upon the process of internalization of image and pertains to the romantic form of art. Painting expresses itself with more freedom in relation to the subjective expression and is manifested in only two dimensions. When the negation of space occurs and the vibratory movement passes one-dimensionally to represent the relations of these vibratory body movements and are related by subjects to the sound phenomenon, then it arrives at the place of music. Music is also considered a romantic art, and it is tied to the subjective temporality and interiority. ${ }^{32}$

Art makes the understanding sensible. Along the same lines, music makes sensible a rational and historical structure and its transformations - it makes sensitive the fact that this rational structure composes itself in many ways, not only formally, but also in the play between its composition and its reception, what is related to the social outline in which it inserts itself. By means of this play, it composes its meaning which is connected to an intuition-of-world or worldview [Weltanschauung]. ${ }^{33}$

\footnotetext{
31 See Hegel, Ästhetik II.

32 See Hegel, Ästhetik I, 116-123; Hegel, Ästhetik II, 259-263.

33 See ibid., 103; Pocai, Philosophie, Kunst und Moderne, 92.
} 


\section{Historicity of music through Hegel}

With Hegel, it is possible to conceive music as configuring feelings and emotions while also being the objective expression of these feelings. In such way, the musical configuration can be conceived as an objective structure of emotions and its connections, in a way that each work of music is a network of affections that, in its entirety, forms an "ethos" of the work. The ethos expressed by the whole of these works, by the rules that determine it (the artistic movements, the systems of rules - tonal, atonal, modal, etc.) and by the comprehension, reception and discourses that they generate, manifests an age and a particular configuration of the general rationality (or Geist). Therefore, it is a historical manifestation.

Hegel divides the structural formation of music into three parts, namely: (1) in its relationship with time (temporality), as duration, as bar or measure (or measured time and beat), and as rhythm;34 (2) harmony; (3) melody (or, in Hegel's terms, "the soul that animates sounds"). ${ }^{35} \mathrm{My}$ focus here will be on harmony, which is the point one must examine in order to compare with Schoenberg's music. ${ }^{36}$

Hegel considers harmony as the difference of pitch and duration of sounds, as depending on "its varying length or shortness, and the number of vibrations it makes during a specific time, it sounds differently. Therefore this is something which art must seize upon and mold to its artistic purpo-

\footnotetext{
34 Hegel, Ästhetik III, 162.

35 Ibid., 162-163.

${ }^{36}$ Here I do not intend to make a comparison and analysis between Hegel and Schoenberg's thought in terms of similarities and differences. My aim is to focus on the convergences between them. Schoenberg takes the harmonic composition of sound to develop his notion of progression of listening. To understand the whole range of harmonics that a note has is the final purpose of musical listening. On the other hand, these harmonics are potentially infinite. The main difference between Hegel and Schoenberg is that Schoenberg takes this "realist" point, an object (the composition of sound) as a starting point, while for Hegel everything should be produced. What Schoenberg calls "emancipation of the dissonance" I call Aufhebung of consonance-dissonance as key reference to listening. Through this Aufhebung one can reach what Schoenberg called "impressionist listening".
} 
ses." ${ }^{37} \mathrm{Hegel}$ considers this sounding element through three perspectives; translating his terms to contemporary technical musical usage, we can say that he considers timbre, pitch and the relationship between pitch and its intervals. At this point, some observations must be made, and later some comparisons in relation to Hegel's conception of what are the most basic elements for what he considers to be music (and which are the most appropriate elements to music as well). This is made in relation to a specific conception that (like the Western history of music, global music, and musical anthropology show) can be understood as limited to a specific historic conception, namely Western music before the Twentieth Century, or between the age of Renaissance and the end of Romanticism.

The point where Hegel reproduces and naturalizes the musical system as a tonal system in a clearer manner is in the system of chords. In dealing with music, Hegel used the beliefs and knowledge of his own time, without questioning the process of constitution and historic transformation of music. His analysis contains some philosophical elements, like the organization of musical elements deduced from extra-musical elements (e.g., the rhythm from the time, the harmony from the sound, and so on), as well as bringing philosophical elements like the place of music in relation to the formation of subjectivity and of interiority, the relationships of these with time and emotions, as well as a critical reflection about how music does not express clear content. However, it is still able to give emotional "enclosure" to verbal contents, making a reflection in this issue in relation to independent music, that is, outside any extra-musical context (what could be called "instrumental music," even if the voice can be used as an instrument).

Hegel's analysis starts with the consonant chords, which are defined by him as chords constituted by the tonic, the third and the fifth notes, and where there is no contradiction. In these chords, "no opposition or

37 Ibid., 171-172. English translation: G. W. F. Hegel, Aesthetics II: Lectures on Fine Art, trans. T. M. Knox (Oxford: Clarendon Press, 1988), 919. 
contradiction arises and their complete concord is unimpaired." 38 It is here that the concept of harmony in "the very nature of that conception, is expressed in its simplest form." 39 This is the "immediate" point to which the reflexive movement returns, as well as being the starting point of the next mediations (in tonal harmony it is the first and central chord, while the tonic of this chord is tonic or central note of the melodic movements).

These mediations, however, happen only by means of a "disturbance" of stability, sonorously represented by the consonance, which obliges the musical movement to return to itself (mirroring here the speculative-dialectic logic) in a phenomenological movement that unfolds its structure in accordance to judgments and the possible inferences to reach its immanent telos or finality. In order to have the reflexive movement, it must have mediation through the disturbance of its immediate identity by the specific difference, which is characterized by Hegel as the dissonance, brought mainly by the addition of the seventh major or minor to the triads.

Hegel was probably referring to the $V_{7}$ chord, which brings in itself both the leading-tone (in melodic sense, which is that note that works as a major seventh of the tonic, as it happens with the note " $B$ " in relation to " $C$ " - supposing that the tonic here is " $C$," being one semitone up) and the dissonance in the chord caused by the tritone interval - or diminished fifth - between its third major and seventh minor $(B-F) .^{40}$

The musical movement must mirror the structure of the concept (in the logical Hegelian sense), and then it must also contain in itself the three logical moments of thought: the moment of immediate or of in itself (tonic, consonance), the for itself moment or the specific difference (dissonance, mediation) and the resolution of this movement through the return to tonic and to consonance (the moment where the consonance

\footnotetext{
38 Hegel, Ästhetik III, 182/ Hegel, Asthetics II, 927.

39 Ibid., ibidem.

40 In a C scale the fifth degree is " $G$ ", and the dominant chord is formed by the notes "G-B-D-F", sounding a diminished fifth between " $\mathrm{B}$ " and " $\mathrm{F}$ " - and vice-versa, once this is a symmetric relationship.
} 
shows itself as the necessary resolution, but one that contains dissonance, being now both consonance and dissonance united through the whole of this mediation, the moment of the in-and-for itself - the whole harmonic cadence). ${ }^{41}$ Dissonances cannot maintain themselves once that they

present to the ear nothing but a contradiction [and] must be resolved if satisfaction is to be given to the ear and heart. Consequently along with the contradiction there is immediately given the necessity [Notwendigkeit] for a resolution [Auflösung] of the discords and the return to the triad. Only this movement, as the return of the identity into itself, is what is simply true. ${ }^{42}$

This movement is related with an immanent necessity of the relationship between sounds and its implicit logic, which, as it was already shown, must resolve such contradiction, being this expressed musically by the supposed perturbation caused by dissonance. Hence, the harmonic cadences themselves have their own range of relationships limited by this necessity that opens a field of possible inferences (harmonic cadences and melodic developments), as well as makes impossible and prohibited (or, still, without meaning or against the logic) certain harmonic relations, once that these cannot be simply mediated by the arbitrariness, but "the movement from chord to chord must partly rest on the nature of the chords themselves and partly on the keys into which they pass".43

My idea here is to apply the Hegelian perspective on the history of art to music. Hegel's conception of art is related to a certain kind of human activity

\footnotetext{
41 Alain Patrick Olivier develops a relationship between Hegel's dialectics and Beethoven Sonatas. See A. P. Olivier, Hegel et La Musique: De l'expérience esthétique à la spéculation philosophique (Paris: Honoré Champión Editeur, 2003), 231-250. The idea is very interesting and deserves more development, considering in-depth the relation between Hegel's Logic and music. Despite that, I prefer to think of Hegel's speculative-dialectics not only as a way to compose pieces of music, but as a wider logic that is immanent to music historical development and to the relationships between the pieces and styles, as I will show in the next chapter.

42 Hegel, Ästhetik III, 184/ Hegel, Aesthetics II, 928.

43 Ibid., 184/929.
} 
on social level, where a community tries to communicate the logical Idea already implicit in the rational structure of society and in individual rational capacities. This Idea must be expressed and must appear in a material way. Art manifests the first appearance of the social self-understanding. As the Idea is universal, the way different cultures and societies express it is related to the whole of human cultural development. In this sense, there is a historical development of human self-consciousness that depends on its social relation. ${ }^{44}$ Art is a form of expression that depends on social relation: only in society can art fulfill its role. ${ }^{45}$ The meaning of art is not art itself (this could be, maybe, a perspective of art after the romantic art, i.e. after the so-called "end of art"), ${ }^{46}$ but human striving for meaning. Hegel relates this striving to Geist, which is the human conscious manifestation of the rational, which has as its logical structure the logical Idea. ${ }^{47}$

44 "Understanding the various relationships between what Hegel calls the absolute-universal, absolute knowledge, the absolute, the absolute idea and absolute spirit would require several independent studies. But if we take our bearings from the basic structure of the Encyclopedia - Logic-Nature-Geist - or postulate that there is a logical position possible on, a conceptual clarification of, the compatibility of Nature and Geist, we shall have enough for this account of Hegel's Lectures on Fine Art. Likewise, we should pause briefly and note the audacity of the claim itself, that 'Philosophy has the same end as art and religion.' [...] This comprehension of that 'same content' - the achievement of which is understood to be the realization of human freedom - is understood by Hegel as a comprehensive form of Geist's self-knowledge, where Geist is understood as a collective subject, a communal or common like-mindedness inheriting the aspirations of a distinct artistic, religious and philosophical tradition and as finally fulfilling those aspirations [...]'. Pippin, After the Beautiful, 06-07.

45 Considering that art is one of the three forms of realization of the absolute Geist, and that the absolute Geist is the realization of the relation between the subjective Geist (individual cognitive and practical capacities) and the objective Geist (the political, economic, moral and ethical relations between the individuals), I believe that it is possible to understand the absolute Geist as a way a society or community tries to realize and understand its own self-identity. See Hegel, Enzyklopädie III.

46 See mainly Hegel, Ästhetik I, 25.

47 „Wenn wir, was die absolute Idee in ihrer wahrhaftigen Wirklichkeit sei, kurz bezeichnen wollen, so müssen wir sagen, sie sei Geist, und zwar nicht etwa der Geist in seiner endlichen Befangenheit und Beschränktheit, sondern der allgemeine unendliche und absolute Geist, der aus sich selber bestimmt, was wahrhaft das Wahre ist." Hegel, Ästhetik I, 128. Emphasis by the author. English: "If we wish to indicate briefly what the absolute Idea is in its genuine actuality, we must say that it is spirit, not, as may be supposed, spirit in its restrictedness and involvement with the finite, but the universal infinite and absolute spirit which out of itself determines what is genuinely the true." Hegel, Aesthetics I, 92. See also Hegel, Enzyklopädie III, §377. 
Art (together with religion and philosophy) is a process of self-understanding, ${ }^{48}$ which is oriented by the logical Idea. This process of orientation involves communication and a kind of pre-conscious understanding, that at the same time the work of art is not the meaning it tries to express. As the purpose is the Idea, the meaning, the material form of art is one mean to its expression. The reception and the meaning it will have in social relation is the final purpose. However, this meaning must have a material expression in order to be communicable, even to the artist himself. 49

The historical development of this meaning through art is represented in Hegel's thought through the conception of "particular form of art," as we have seen. The art and the artistic expressions form a whole..$^{\circ}$ Considering this, it is possible to infer that this historical development is also implicit in the singular forms of art. ${ }^{51}$

Music is classified by Hegel as a romantic form of art. That means that music is an artistic expression that points to a content or meaning that is beyond its sensual and material form. Nevertheless, Hegel's conception of the historicity of art is related to particular forms of art. Does this mean that those moments in history before the rise of Christianity did not have music? One should consider the difference between a "plastic" conception of music and a properly "musical" conception of music.

48 „In Kunstwerken haben die Völker ihre gehaltreichsten inneren Anschauungen und Vorstellungen niedergelegt, und für das Verständnis der Weisheit und Religion macht die schöne Kunst oftmals, und bei manchen Völkern sie allein, den Schlüssel aus. Diese Bestimmung hat die Kunst mit Religion und Philosophie gemein, jedoch in der eigentümlichen Art, daß sie auch das Höchste sinnlich darstellt und es damit der Erscheinungsweise der Natur, den Sinnen und der Empfindung näherbringt." Hegel, Ästhetik I, 21. English: "In works of art the nations have deposited their richest inner intuitions and ideas, and art is often the key, and in many nations the sole key, to understanding their philosophy and religion. Art shares this vocation with religion and philosophy, but in a special way, namely by displaying even the highest [reality] sensuously, bringing it thereby nearer to the senses, to feeling, and to nature's mode of appearance." Hegel, Aesthetics I, 07-08. See also Ästhetik I, 150-151.

49 See Bertram, Kunst, 124-135.

50 See Hegel, Ästhetik II, 245-265.

51 In other singular forms of art Hegel explicitly develops an historical conception, which he does not with music. 
According to Nowak, the ancients have considered music as closer to plastic arts: "These arts [singing, music and poetry] have, for sure, in the ancients already acquired, alongside the plastics, a higher development, without disengaging themselves from one another and from their spatial existence [Dasein] - the dance - and without making possible this Becoming-free-interiority [Freiwerden Innerlichkeit] in the sense meant here." ${ }^{12}$ It seems that Hegel accepted this view, and thus we can infer that, although music had existed since antiquity, only through the development of the romantic form of artistic consciousness and through the discovery of interiority, was it possible to experience music as "musical music." Only through this shift can music be independent of bodies and become content for the soul or, to be specific, the internal form of soul is music's content. That means that music is somehow "formal" since its own true source. Romantic art is a non-mimetic perspective on art.

Music in the ancients' view (mainly the Greeks), from the point of view of Hegel and others in the Nineteenth Century, was connected to the natural, to the movement of speech and its rhythm as syllable and so on, which in turn was connected to the bodily and natural movements. The romantic character would be connected to another, non-bodily conception of time - time as "internal." The progression into this time conception is not only a different conception of music and art but also a different way to feel and experience time. This makes the pure musical experience of music possible. ${ }^{53}$

Hegel divides the process of the romantic form of art in three parts: the first is related to human finitude, but striving toward infinite ascension; the second is related to the negation of the finite world from an intimate and religious perspective that takes itself as a starting point and then negates every mundane reality; in the third and last level this subjectivity which knows itself as infinite meets again with the finite, finding itself again in a context where it can freely deal with this finite content. This whole

\footnotetext{
52 Adolf Nowak, Hegels Musikästhetik (Regensburg: Gustav Bosse Verlag, 1971), 195.

53 See ibid., 195-198.
} 
process is expressed through the main motivation of the perspective of romantic art: love. It represents love as (1) aspiration to transcendence, (2) the love for the infinite God (to universality) and (3) the singularized love for another individual (which features the return to finite things). ${ }^{54}$ In the third part of the process, where there is the "decay" of the romantic form of art (which in turn represents the decay of art as "highest truth"), infinite subjectivity is found, apart from externality (which on its turn is also infinite, an infinite number of finitudes). This subjectivity now deals with mundane contingencies and singularities, until it loses its substantiality. It drops itself in the contingency, sacrificing its connection to necessity and universality of Geist's development. In other words, the artist loses himself in the prosaism of objectivity, in the details of daily life. 55

Once its relationship to romantic art is understood, music seems (1) to fulfill a role in the development of Christian consciousness and (2) to surpass its role in the development of Geist and then be "free." Music also has a tendency to be autonomous, which means that music historically thought, develops itself as "pure" or instrumental music (including here, of course, singing as a possibility, but without consideration of lyrics). On the other hand, both art and music have lost their substantiality. ${ }^{56}$

I would like to present a historical conception of the development of academic Western music using the figures of tonal music and twelve-tone music. I propose that music develops historically in a way related to the cultural general structure of reason; that is, in accordance with the historical structure of the manifestation of the logical Idea. This logical Idea changes historically, and instead of being a pre-existing logical structure that predetermines history, it searches for coherent diversity in the widest possible form.

\footnotetext{
54 See Pocai, Philosophie, Kunst und Moderne, 255-265.

55 See ibid., 272

56 See Nowak, Hegels Musikästhetik, 204-209.
} 
The concept of Aufhebung makes it possible to think the overcoming of an older "way of doing" or an older logical structure in a manner that allows the older structure to be assimilated by the new one, but with a new meaning. Here I argue that this process can be seen in music history, considering the development of tonal music as a figure of social reason and twelve-tone music as a new musical logic that can comprehend tonal music and non-tonal music in a new unity - a new kind of musical understanding.

The idea here is that a rational particular figure [Gestalt $]^{57}$ (like a kind of way of doing and understanding music) develops itself until its saturation. After that, a new antagonistic model is created at the first moment, and in the final stage, there is an assimilation of this sublated [aufgehoben] figure (that includes the antinomy) in a new wider form of doing and understanding (in this case, a new kind of musical understanding).

\section{Schoenberg, musical progress and Twelve-tone music}

At the beginning of the Twentieth Century, academic music ${ }^{58}$ sought new paths that can be divided in a simplified manner, between the search to avoid tonalism, through modalism inspired by folk themes or the systematic escape of tonalism through atonalism or systematizations alike. ${ }^{59}$

\footnotetext{
57 I take here the idea of "figures of reason" inspired by the Phenomenology of Spirit, considering "figure" as translation for "Gestalt", and recognizing this as a "plastic/material form", while the term "Form" can be translated by logical form. In this sense, there are processes of "figurations" (Gestaltungen) which are the processes or activities that produce figures, which can be seen as configurations of relations, thus configuring relations, identities and subjects (considered here not only as individuals, but also as a social product - a specific nation or, as I defend here, an art movement or a musical system). See mainly Hegel, Phenomenologie.

${ }_{58}$ Or erudite music. I avoid to use the term "classical music", since "classical" is also a period of the history of music and a musical model or style.

59 One can also think here about Debussy, who, using scales with 6-tones (or hexatonics), avoids the gravitational movement called by the relationship between the sensible and the tonic. I believe this is closer to the first case (modalism). For more on the history of music, see D. Grout; C. Palisca, História da Música Ocidental, fifth ed., trans. Ana Luísa Faria (Lisboa: Gradiva, 2007); R. Candé, História Universal da Música, 2 Vol., trans. Eduardo Brandão (São Paulo: Martins Fontes, 2001); Otto Maria Carpeaux, O Livro de Ouro da História da Música: Da Idade Média ao século XX. Fifth ed. (Rio De Janeiro: Ediouro, 2001).
} 
Even in musical movements continuous to tonalism, it is possible to find constant suspensions and dissonances that, if compared to the traditional classicist model that can be considered as the official representative of the tonal model, moves away from the central rules and tendencies. ${ }^{60}$

The music made at the margins of the tonal system only acquires meaning and form through the tonal paradigm - the first is constructed in the last. ${ }^{61}$ In a different way, the system that is opposed to the tonal system is constructed against it. Along these lines, both are connected to the tonal system, but the first as pertaining to it immanently and the other extrinsically (antinomically). Schoenberg's twelve-tone music is the latter case. ${ }^{62}$

This new model brings together new forms of understanding music and of perceiving its basic elements, such as its rhythms and intervals - as well as the relationship between consonance and dissonance. It is possible to understand that musical perception cannot be explained only through the relationship between the human and nature (i.e., in a naturalistic way $\left.{ }^{63}\right)$, but the perceptions themselves are constituted through habit in accordance with the construction of objects that stimulate perception (i.e., at least partially in a historical and contextual manner). ${ }^{64}$ Considering

\footnotetext{
60 See Gunnar Hindrichs, Die Autonomie des Klangs (Berlin: Suhrkamp, 2014), §184, 198-199.

61 When a composition uses modulation and leads it to its extreme, like some cases in Wagner and late Romanticism.

62 I claim here that Schoenberg's harmonic conception changes the way of composing, understanding and listening to music; in this sense, it is not only the antinomy of tonal system, but its Aufhebung, because its conception includes a way to compose and also understand tonal music. Considering historically the process of its construction, it also has a negative relationship to tonal music as its necessary moment. I am considering here not only Schoenberg's compositions, but mainly his harmonic theory and his view on music and its historical development.
}

${ }_{63}$ As Rameau and also some contemporary conservatives defend. See Jean-Philippe Rameau, Traité de l'Harmonie: reduite à ses principes naturels (Paris: J. B. C. Ballard 1722)/ English translation: Jean-Philippe Rameau, Treatise on Harmony, trans. Philip Gossett (New York: Dover Publications, 1971); A. Papodopolus, "Mathematics and music theory: From Pythagoras to Rameau," The Mathematical Intelligencer, Volume 24, no. 1, (2002): 65-73; Brian K. Etter, From Classicism to Modernism: Western Musical Culture and the Metaphysics of Order (Aldershot: Ashgate, 2001).

${ }^{64}$ For a cognitivist approach see Aniruddh Patel, Music, Language and the Brain (Oxford: Oxford University Press, 2008). 
that some musical note intervals or some musical configurations are recurrent because they are innate in the relationship between human constitution and nature, or that they are objects in nature, or yet subjective innate configurations, is a way of thinking that disregards the variation of human understanding and confuses the limits of understanding with an idea of perfection. Most of the time ideas of perfection are based on historical constructions, and even if it were possible to find some musical configuration that could actually express a kind of perfection, it would not mean that music and its understanding are reduced to the search for perfection. Schoenberg puts this issue as following:

One could conclude that that activity, that movement which produces music, is the activity implicit in the tonic alone, the activity created by the relation of its two satellites [namely, the degrees I and V of the harmonic field] to it and to each other. This relation, being so completely consistent, so clearly definable, seems so remarkable that it could give one the notion that this or something similar must be found in all music if it is really to be music. But that just does not have to be so; besides, perhaps the search has just not been carried far enough, and for that reason, perhaps, other discoveries have not been made. For it is quite probable that the higher, the more complicated numbers, the more complex harmonic relations conceal in themselves a still richer Mystik than that of the prime numbers, of the irreducible, simpler harmonic relations; and on this probability is based the hope for a future development still richer in interesting secrets. Consequently, I think it is important to stress all these remarkable things so frequently that they can never be forgotten; for I am certain they also hold the key to the phenomena that at present are still obscure to us. ${ }^{65}$

65 Arnold Schoenberg, Harmonielehre: dritte Auflage (Vienna: Universal-Edition, 1922), 161-162. English translation: Arnold Schoenberg, Theory of Harmony, trans. Roy E. Carter (Los Angeles: University of California Press, 1978), 132. 
Through the diversity of meanings and sensations that music brin$\mathrm{gs}$, it is possible to relate musical configurations to something external - models of understanding and rationality. When a music model repeats itself until its exhaustion, even that which could be initially rejected as unpleasant and prohibited starts to make sense, because human relation to art and to music involves not only seeking pleasure and entertainment but also self-comprehension, social construction and the development of rational and aesthetic diversity. ${ }^{66}$

Therefore, we can think that atonal or twelve-tone music (despite using intervals taken as unpleasant and having a tense sonority, from the point of view of a tonal listening/understanding at least) can become meaningful in a time when a musical model comes to its exhaustion (namely, tonal model). The incomprehension or rejection of certain artistic productions can also express (along with the analysis of reasons for its productions) models or figures of the rationality of the time and society in which it happens. Schoenberg's twelve-tone music and his school can be understood as the necessity of negation of a specific model of production (tonal model). ${ }^{67}$

While tonal music is constituted in accordance with the appropriation and systematization of a set of relations that, once assimilated by a social rationality, become inclined to its reproduction (both in composition and in listening), atonal music must search for its means of negation through the comprehension of the tonal model itself. Twelve-tone music (as non-tonal music) constitutes itself through an internal analysis of the tonal model, seeking its escape points (so it is a consequence of immanent negativity).

\footnotetext{
${ }_{66}$ I believe it is in accordance with Hegel's conception of Idea, which is Actuality [Wirklichkeit] itself, seeking for the unity of the richest plurality. The absolute Idea is not a final static point, but is itself the maintenance of the movement as searching for coherence, in its wider and universal level (which includes the particular and the diversity of singulars, each in its own singularity). Because of the constant movement of dialectics and Aufhebung, the Idea is constant movement. See Hegel, Enzyklopädie I, §216; G. W. F. Hegel, Werke 6: Wissenschaft der Logik II. (Frankfurt am Main: Suhrkamp, 1990), 464-466.
}

${ }_{67}$ See Schoenberg, Harmonielehre, 388-389/ 321. 
Schoenberg's twelve-tonic conception can be understood as an immanent critique to the tonal system in the following way:

a) It is conceived in a notion of historical progress, which Schoenberg makes explicit in Harmonielehre:

Once again: the tone is the material of music. It must therefore be regarded, with all its properties and effects, as suitable for art. All sensations that it releases - indeed, these are the effects that make known its properties - bring their influence to bear in some sense on the form of which the tone is a component, that is, on the piece of music. In the overtone series, which is one of the most remarkable properties of the tone, there appear after some stronger sounding overtones a number of weaker-sounding ones. Without a doubt the former are more familiar to the ear, while the latter, hardly perceptible, are rather strange. In other words: the overtones closer to the fundamental seem to contribute more or more perceptibly to the total phenomenon of the tone - tone accepted as euphonious, suitable for art - while the more distant seem to contribute less or less perceptibly. But it is quite certain that they all do contribute more or less, that of the acoustical emanations of the tone nothing is lost. And it is just as certain that the world of feeling somehow takes into account the entire complex, hence the more distant overtones as well. Even if the analyzing ear does not become conscious of them, they are still heard as tone color. That is to say, here the musical ear does indeed abandon the attempt at exact analysis, but it still takes note of the impression. The more remote overtones are recorded by the subconscious, and when they ascend into the conscious they are analyzed and their relation to the total sound is determined. But this relation is, to repeat, as follows: the more immediate overtones contribute more, the more remote contribute less. Hence, the distinction between them is only a matter 
of degree, not of kind. They are no more opposites than two and ten are opposites, as the frequency numbers indeed show; and the expressions 'consonance' and 'dissonance', which signify an antithesis, are false. It all simply depends on the growing ability of the analyzing ear to familiarize itself with the remote overtones, thereby expanding the conception of what is euphonious, suitable for art, so that it embraces the whole natural phenomenon. ${ }^{68}$

The key to the historical progress is the progress of listening as a capacity to harmonically assimilate the intervals that compose sound, that is, the harmonic series. Along these lines, Schoenberg relates a naturalist element (the physical constitution of sound) with a cultural-historical process of constitution of listening, this last oriented by the progress as enlargement and diversification. This broadening of listening comprehension is related to the conception of consonance and dissonance, which modifies itself according to the progress of audition. Since the tonal model is conceived in a logic that has an idea that determinate relations (considered as consonants) form the basis of a system of understanding, when the conception of consonance and dissonance changes, it also changes the basis of this system. Hereby, we can conceive the initial development of twelve-tone music as a split (opening to Aufhebung) in the tonal system of understanding that arises from the development of tonal model itself, thus being a process of immanent critique and a constitution through negativity; ${ }^{69}$

\footnotetext{
68 lbid., 17-18/ 20-21. Emphasis are mine.

69 The theoretical basis to justify tonal model is the consideration of the harmonics (or overtones) of each note as the justification of what is consonant and dissonant in musical listening. The intervals that sound stronger are the same intervals that constitute consonance relations. The major triad was considered the model of consonance, while dissonance should always be resolved in a return to consonance (dissonance can be understood as the negative motor of the musical movement). With the assimilation of some dissonant intervals and the habit to accompany more complex and long harmonic cadences, with more and more modulations, musical harmony became progressively complex and dissonant. The physical theory of sound was then an element of justification of the naturalization of a way of doing music. Schoenberg's
} 
b) the field of musical understanding can be conceivedas being established in certain limits that serve as basis for the expansion of this understanding. Thus, more simple forms of understanding are logical and historical presuppositions to the development of wider and more complex forms of understanding. From this process of enlargement, the transformation of the basis of understanding itself becomes possible, through the Aufhebung; ${ }^{70}$

c) the scientific progress in physical acoustic collaborates to this new conceptions, as well as to the previous conceptions (namely, to those that were used to justify or naturalize tonal music model).

Schoenberg developed not only a new kind of composition but also a new idea of music - including, mainly, a new way of understanding and perceiving it. He called it "impressionist listening":

Perhaps the future of our music speaks through this freshness. It is heard only by those who are highly sensitive to impressions, the impressionists. The impressionist's organ [of perception] is a mechanism of extraordinarily fine tuning, a seismograph, which registers the slightest motion. The most delicate stimuli can arouse his sensibility, whereas crudeness shatters it. To pursue these most delicate stimuli, which the coarser nature never perceives because he hears only what

\footnotetext{
idea is not that it is simply false, but harmonics that compose sound are much larger than the simple initial ones (physics shows that, and we must also consider that the harmonics change depending on the material that reverberates, and that is what we call timbre or sound color). There is a historical progress of audition, which more and more seeks to perceive the elements (harmonics) that constitute sound and it is mirrored by musical harmony. Tonal harmony is, in this view, a necessary historical moment for human listening progressive development, though this model came to the moment of its necessary sublation. For an acoustical definition of harmonics, see David M. Howard and James Angus, Acoustics and Psychoacoustics: Second edition (Oxford: Focal Press, 2001), 51-53.

70 See the idea of perspective in music: Hindrichs, Die Autonomie des Klangs, §142, §160. Through this point, it is possible to establish a relationship between historical developments of music and painting. See also A. H. Lian "Do Cubismo Musical: Uma investigação em estética comparada". (PhD diss., University of São Paulo, 2008).
} 
is loud, is a powerful temptation to the true impressionist. What is soft, scarcely audible, hence mysterious, attracts the impressionist, arouses his curiosity to savor what was never tried before. Thus, the tendency of something unheard-of to reveal itself to the searcher is just as great as is the tendency of the searcher himself to find something unheard-of. And in this sense every truly great artist is an impressionist: ultrafine reaction to the slightest stimuli reveals to him the unheard-of, the new. ${ }^{71}$

However, this new understanding is not simply historically independent of the old one: it is a continuation of the way of listening to that generated tonal music. The historical connection between different kinds of musical conceptions is the idea of sound and its components, the harmonics. Schoenberg's idea is that human listening develops in understanding and listening better to the elements of sound. An interval relationship that was seen as "sounding bad" or "sounding conflicted" was considered a "dissonance." The opposing idea of consonance is the key of tonal music, and the dissonant variants of the consonances were the motor of tonal music's movement. With the development of tonal music and the development of listening, new kinds of dissonances and interval relations were incorporated to tonal music. ${ }^{72}$ In the Twentieth Century, the possibility of a new conception of the relationship between sounds was opened. Schoenberg considers that pitch is only one aspect of timbre (or sound color), one direction of it, and that other aspects could be considered in the future:

Now, if it is possible to create patterns out of tone colors that are differentiated according to pitch, patterns we call 'melodies', progressions, whose coherence [Zusammenhang]

\footnotetext{
71 Schoenberg, Harmonielehre, 482-483/402-403.

72 It is possible to perceive this logical enlargement of harmony during the development of Nineteenth Century music, in the so-called Romantic period.
} 
evokes an effect analogous to thought processes, then it must also be possible to make such progressions out of the tone colors of the other dimension, out of that which we call simply 'tone color', progressions whose relations with one another work with a kind of logic entirely equivalent to that logic which satisfies us in the melody of pitches. That has the appearance of a futuristic fantasy and is probably just that. But it is one which, I firmly believe, will be realized. I firmly believe it is capable of heightening in an unprecedented manner the sensory, intellectual, and spiritual pleasures offered by art. $^{73}$

Following Schoenberg's idea, it is possible to say that there is an overcoming [Aufhebung] of the dichotomy between consonance and dissonance. The sound, or the note, is composed by (possibly infinite) harmonics, but some sound louder or "first" than others. The relationship between notes should mirror this relationship, ${ }^{74}$ and then the conception of dissonance and consonance is related only to human listening limitation. However, according to Schoenberg, this listening and understanding limitation changes in history, in accordance with full comprehension and listening of sound and its components (to the infinite). However, this implies a new logical order to the musical system. This new logic is recognized by Schoenberg as a historical necessity of human listening progress. It is possible to relate it to Hegel's conception of the historical progress of human comprehension. On the other hand, art has already fulfilled its role in the formation of the Geist's self-comprehension - after romantic art, it becomes "autonomous," which means that its meaning is not dependent on its role in human or Geist general forms of self-comprehension.75 Considering that Hegel places music as a romantic form of particular art, how can we understand the historical development of music?

\footnotetext{
73 Schoenberg, Harmonielehre, 506-507/ 421-422.

74 This belief is the basis of Rameau's naturalism. See Rameau, Traité de l'Harmonie.

75 See Hegel, Ästhetik I, 25; Hegel, Ästhetik II, 220-242.
} 
One important point here is that particular forms of art (including romantic) have an internal development. Therefore, music plays a role in the development of the romantic form of art. In addition, the romantic form of art is the level where art transcends its general role. This means that music, together with art in general, transcends its dependence on the absolute Geist's formation. At the same time, Geist no longer depends on art to express and recognize the higher level of truth and self-knowledge. Nevertheless, why would there still be a historical development?

In this sense, music is considered as a particular manifestation of the general historical reason /Geist. If it is possible to accept that twelve-tone music is a new and relevant musical event, then there still is a historical process in art.

The particular romantic form of art is the level of artistic consciousness where the content is deeply connected to interiority, to subjectivity and its freedom. This inner subjectivity is related to the infinity of Geist, namely its continuous capacity of self-transcendence. Romantic art realizes itself in a cultural moment when externality is placed secondary rather than essential, despite the external material being necessary to the expression of artistic content; that is, the internal cannot be artistically manifested, but through externality and the infinity of Geist cannot be artistically manifested but through the finitude of singularization.

The limit of this possibility of autonomization of the subject against the external material is what will determine how Hegel's philosophy of art can behave in face of Schoenberg's twelve-tone music event. At the moment when art reaches full autonomy before its material, having its meaning and its possibilities of expression gone beyond the limits imposed by externality, we would have to accept that Schoenberg's art fits perfectly well in the Hegelian conception of romantic art. Since issues like the ideas of consonance and dissonance, of tonality and all the structure of relations between melody, harmony, and timbre are questioned by Schoenberg (as well as the naturalization of artistic perception and intuition), there is a relationship between this attitude and the spirit of what Hegel called 
romantic art. On the other hand, the inclination of Hegel's thought is to articulate differentiations in order to articulate forms of reconciliations between those elements that are external to one another in the end.

\section{Conclusion}

I conclude by pointing to the paradox in the relationship between hope for meaning (expressed in art) and the Hegelian idea that art no longer takes part in the generation of new meanings and levels of consciousness after the rise of philosophy and modern society. On the other hand, both art (in general) and music (in specific) show that since the beginning of the Twentieth Century there are new ways to be explored, that its techniques and tools are connected to the effort to bring about new meanings and experiences (which could be already present in daily life, at a specific historical moment). These new meanings and experiences could be considered as dependent on new forms of expression to become known. For Hegel art, religion and philosophy exist in a relationship in which one does not nullify the other; they complement each other through necessity. However, there is a hierarchy. Thus, if it is understood that there is a possibility of making thoughts intuitive, instead of only making intuitions thinking, then there is an open possibility to think, in analogy, about a relationship of feedback between philosophy and art. According to Hegel, "intuition is, thus, only the beginning of cognition"76 and yet:

The complete cognition [Erkenntnis] pertains only to the pure thinking of conceptualizing reason [reinen Denken der begreifenden Vernunft], and only those who raised themselves to this thinking have a truly completely determined intuition; only through thinking can one construct the solid Form of

76 Die Anschauung ist daher nur der Beginn des Erkennens." Hegel, Enzyklopädie III, §449, Zusatz. The translation is mine. 
intuition, in which its complete developed cognition is once again compressed. ${ }^{77}$

We must also consider that:

In feeling [Empfindung] it is present the whole reason - the complete material of Geist. All our representations, thoughts and concepts of external nature, legality, ethics [Sittlichen] and of the content [Inhalt] of religion develop themselves from our sensible intelligence [empfindenen Intelligenz]; on the other hand, it will concentrate itself in the simple form of intuition, after they reach their complete explanation. The ancients have correctly said that humans have formed their gods from their feelings and passions. Each development of Geist tends to be understood as if the intelligence was originally empty and then all content would come from outside, as something wholly strange. It is a mistake. That which the intelligence seems to absorb from outside is actually nothing other than the rational. Therefore, the Geist is identic and immanent to it. The activity of Geist has, then, no other finality than to refute the appearance, through the Aufhebung of the being-itself-external of the object rational in itself, that the object is external to Geist. ${ }^{78}$

\footnotetext{
77 „Die vollendete Erkenntnis gehört nur dem reinen Denken der begreifenden Vernunft an, und nur derjenige, welcher sich zu diesem Denken erhoben hat, besitzt eine vollkommen bestimmte wahrhafte Anschauung; bei ihm bildet die Anschauung bloß die gediegene Form, in welche seine vollständig entwickelte Erkenntnis sich wieder zusammendrängt.“Ibid., §449, Zusatz. The translation is mine.

78 "In der Empfindung ist die ganze Vernunft, - der gesamte Stoff des Geistes vorhanden. Alle unsere Vorstellungen, Gedanken und Begriffe von der äußeren Natur, vom Rechtlichen, vom Sittlichen und vom Inhalt der Religion entwickeln sich aus unserer empfindenden Intelligenz; wie dieselben auch umgekehrt, nachdem sie ihre völlige Auslegung erhalten haben, in die einfache Form der Empfindung konzentriert werden. Mit Recht hat deshalb ein Alter gesagt, daß die Menschen aus ihren Empfindungen und Leidenschaften sich ihre Götter gebildet haben. Jene Entwicklung des Geistes aus der Empfindung heraus pflegt aber so verstanden zu werden, als ob die Intelligenz ursprünglich durchaus leer sei und daher allen Inhalt als einen ihr gänzlich fremden von außen empfange. Dies ist ein Irrtum. Denn dasjenige, was die Intelligenz von außen aufzunehmen scheint, ist in Wahrheit nichts anderes als das Vernünftige, folglich mit dem Geiste identisch und ihm immanent. Die Tätigkeit des Geistes hat daher keinen anderen Zweck als
} 
It would be possible to think that Hegel's philosophy claims for a peak where thinking negates feeling and lets it aside.The feeling would be something that is only part of the path to thinking but once sublated it has no function anymore. In a similar manner, it is possible to think about the relationship between art and philosophy in culture. However, at first sight, that does not seem to conform to Hegel's proposal.

The dialectical-speculative thinking, however, maintains these relations. Thus, it is possible to think that there is always new intuitive content, as well as conceptual thinking which enables elaborate ways to become intuitive - since the mediation of thinking, in the end, comes back to the form of intuition (in a mediated identity). In these lines, it is possible to think that new cultural content, brought at the level of the absolute Geist through history, can and must be expressed by art in an effort for them to become intuitive. Nevertheless, the function of art is in Modern times is no longer the highest to Geist. Thus, nowadays art should always be in relation to philosophical and conceptual thinking. ${ }^{79}$

Once music does not deal with objectual contents, but with feeling itself and other internal configurations of intimate subjectivity, it is possible to understand that music, as artistic form, brings the form of internal feeling of a social subjectivity, a way to feel and understand sounds that transform themselves through history - which has, thus, historicity. In these lines, the beginning of the Twentieth Century in music reveals,

den, durch Aufhebung des scheinbaren Sich-selber-äußerlich-Seins des an sich vernünftigen Objektes auch den Schein zu widerlegen, als ob der Gegenstand ein dem Geiste äußerlicher sei." Ibid., §447, Zusatz. The translation is mine.

79 This immanent process of historical development of music includes Aufhebung as a logical tool. Despite that, musical immanent Aufhebung does not implies in a new form of spiritual figure of absolute Geist, nor a new kind of particular form of art. Hegel makes clear that there are only three forms of manifestation for the absolute Geist (which are art, religion and philosophy). The problem here is how to relate musical maintenance of historicity with this structure (what means to deal with its function in absolute Geist, and that is what I am trying to answer). Some would prefer to relate modern art in general with a post-romantic art. I believe it is possible to include all historical development of modern art in forms of late romantic art. Also, music is considered by Hegel as a romantic form of art. That means that all its historical processes should be understood inside romantic art. 
with Schoenberg and other composers, new intuitive configurations of this social subjectivity.

\section{Bibliography}

BERTRAM, G. W. 2011. Kunst: Eine philosophische Einführung. Stuttgart: Philipp Reclam.

CANDÉ, R. 2001. História Universal da Música. 2 v. Translated by Eduardo Brandão. São Paulo: Martins Fontes.

CARPEAUX, OTTO MARIA. 2001. O Livro de Ouro da História da Música: Da Idade Média ao século XX. Fifth edition. Rio De Janeiro: Ediouro. https://doi. org/10.17771/pucrio.acad.19349

DENHAM, A. E. 2009. "The Future of Tonality." British Journal of Aesthetics, 49, n. 4 (September): 427-450.

ESPIÑA, Y. 1996. La Razón Musical en Hegel. Navarra: Ediciones Universidad de Navarra.

ETTER, BRIAN K. 2001. From Classicism to Modernism: Western Musical Culture and the Metaphysics of Order. Aldershot: Ashgate.

GONÇALVES, MARCIA. 2017. "Tempo Poético e Tempo Prosaico." Revista Eletrônica Estudos Hegelianos 14, n. 23. http://ojs.hegelbrasil.org/index.php/ reh/article/view/232/200

GROUT, D. AND PALISCA, C. 2007. História da Música Ocidental. Fifth edition. Translated by Ana Luísa Faria. Lisboa: Gradiva.

HALL, G. S. 1873. "Hegel's Science of Absolute Spirit." The Journal of Speculative Philosophy, 7 n. 3: 44-59. http://www.jstor.org/stable/25665837

HEGEL, G. W. F. Aesthetics: Lectures on Fine Art. Two Volumes. Translated by T. M. Knox. Oxford: Clarendon Press, 1988.

HEGEL, G. W. F. 1931. Die Idee Und Das Ideal, ed. Georg Lasson. Leipzig: Meiner. HEGEL, G. W. F. 1990. "Glauben und Wissen oder Reflexionsphilosophie der Subjektivität in der Vollständigkeit ihrer Formen als Kantische, Jacobische und Fichtesche Philosophie." In Werke 2: Jenaer Schriften, 1801-1807. Frankfurt am Main: Suhrkamp.

HEGEL, G. W. F. 1989. Werke 3: Phänomenologie des Geistes. Frankfurt am Main: Suhrkamp. 
HEGEL, G. W. F. 1990. Werke 6: Wissenschaft der Logik II. Frankfurt am Main: Suhrkamp.

HEGEL, G. W. F. 1986. Werke 8: Enzyklopädie der philosophischen Wissenschaften I. Frankfurt am Main: Suhrkamp.

HEGEL, G. W. F. 1986. Werke 10: Enzyklopädie der philosophischen Wissenschaften III. Frankfurt am Main: Suhrkamp.

HEGEL, G. W. F. 1989. Werke 13: Vorlesungen über die Ästhetik I. Frankfurt am Main: Suhrkamp.

HEGEL, G. W. F. 1990. Werke 14: Vorlesungen über die Ästhetik II. Frankfurt am Main: Suhrkamp.

HEGEL, G. W. F. 1990. Werke 15: Vorlesungen über die Ästhetik III. Frankfurt am Main: Suhrkamp.

HEGEL, G. W. F. 2003. Vorlesungen über die Philosophie der Kunst, ed. Annemarie Gethmann-Siefert. Hamburg: Meiner. https://doi.org/10.28937/978-3-78733238-0

HERNÁNDEZ, J. D. 2009. "A arte como formelle Bildung: a estética de Hegel e o mundo moderno." In M. A. Werle and P. F. Galé, eds. Arte e Filosofia no Idealismo Alemão, 77-104. São Paulo: Editora Barcarolla.

HINDRICHS, GUNNAR. 2014. Die Autonomie des Klangs. Berlin: Suhrkamp.

HOWARD, DAVID M., and Angus, James. 2001. Acoustics and Psychoacoustics: Second edition. Oxford: Focal Press.

LIAN, A. H. 2008. "Do Cubismo Musical: Uma investigação em estética comparada". PhD diss., University of São Paulo. https://doi.org/10.11606/t.8.2009. tde-23112009-102427

NOWAK, ADOLF. 1971. Hegels Musikästhetik. Regensburg: Gustav Bosse Verlag. PAPODOPOLUS, A. 2002. "Mathematics and music theory: From Pythagoras to Rameau." The Mathematical Intelligencer, 24, n. 1: 65-73. https://doi. org/10.1007/bfo3025314

PATEL, ANIRUDDH. 2008. Music, Language and the Brain. Oxford: Oxford University Press.

PETERS, JULIA. 2016. "On Naturalism in Hegel's Philosophy of Spirit." British Journal for the History of Philosophy, 24, n. 1: 111-131. https://doi.org/10.108 o/09608788.2015.1055231 
PIPPIN, ROBERT. 2014. After the Beautiful: Hegel and the Philosophy of Pictorial Modernism. Chicago: University of Chicago Press. https://doi.org/10.1017/ hgl.2016.44

POCAI, ROMANO. 2014. Philosophie, Kunst und Moderne: Überlegungen mit Hegel und Adorno. Berlin: Xenomoi. https://doi.org/10.28937/1000106279 RAMEAU, JEAN-PHILIPPE. 1971. Treatise on Harmony. Translated by Philip Gossett. New York: Dover Publications.

RAMEAU, JEAN-PHILIPPE. 1722. Traité de l'Harmonie: reduite à ses principes naturels. Paris: J. B. C. Ballard.

RUTTER, BENJAMIN. 2010. Hegel on Modern Arts. Cambridge: Cambridge University Press.

SCHOENBERG, ARNOLD. 1922. Harmonielehre: dritte Auflage. Vienna: Universal-Edition.

SCHOENBERG, ARNOLD. 1978. Theory of Harmony. Translated by Roy E. Carter. Los Angeles: University of California Press.

WERLE, M. A. 2001. A Questão do Fim da Arte em Hegel. São Paulo: Hedra.

\section{Endereço Postal}

Universidade Federal de Mato Grosso, Instituto de Ciências Humanas e Sociais, Departamento de Filosofia. Universidade Federal de Mato Grosso, Boa Esperança, 78060900 - Cuiabá, MT - Brasil Telefone: (65) 36158000 